\title{
Sosialisasi Aplikasi Pembelajaran Jarak Jauh dan Pengembangan Bahan Ajar bagi Dosen, Guru, dan Mahasiswa di Era Pandemi Covid-19
}

\author{
Syarifuddin $^{1 *}$, Purna Bayu Nugroho ${ }^{2}$, Muhibuddin Fadhli ${ }^{3}$, Murtalib $^{1}$, Mutmainah $^{1}$, Muchlis $^{1}$, \\ Mikrayanti $^{1}$, Ika Wirahmad ${ }^{1}$, Dewi Sartika ${ }^{1}$, Andang$^{1}$, Edi Mulyadin', Arnasari Merdekawati \\ Hadi $^{1}$ \\ ${ }^{1}$ Program Studi Pendidikan Matematika, STKIP Bima, Bima, Indonesia \\ ${ }^{2}$ Universitas Muhammadiyah Kotabumi, Lampung, Indonesia \\ ${ }^{3}$ Universitas Muhammadiyah Ponorogo, Ponorogo, Indonesia \\ *Coresponding Author: syarifuddin.stkipbima@gmail.com \\ Dikirim: 14-06-2021 ; Direvisi: 17-06-2021 ; Diterima: 17-06-2021
}

\begin{abstract}
Abstrak: Pembelajaran jarak jauh (PJJ) sudah dikenal dan diaplikasikan sejak lama melalui program yang diselenggarakan oleh Universitas Terbuka maupun oleh beberapa universitas lainnya. Pelaksanaannya dengan cara pembelajaran melalui modul dan mahasiswa dilakukan ujian diakhir semester secara langsung atau luring. Akan tetapi, semenjak diakhir tahun 2019 dengan adanya wabah covid-19, pelaksanaan pembelajaran jarak jauh menjadi keharusan bagi sekolah maupun perguruan tinggi. Implementasi pembelajaran jarak jauh di era covid19 sangat jauh berbeda dengan pembelajaran jarak jauh yag diterapkan oleh Universitas Terbuka saat itu. Pembeleajaran jarak jauh saat ini dilakukan melalui jaringan internet atau yang biasa disebut dengan pembelajaran daring. Untuk menunjang pelaksanaan tersebut, dosen, mahasiswa, guru, maupun siswa dituntut untuk menguasai penggunaan aplikasi yang dapat digunakan dalam proses pembelajaran daring, misalnya zoom, google meet, whatsshap, dan beberapa aplikasi lainnya. Untuk itu, program studi pendidikan matematika STKIP Bima mengadakan sosialisasi penggunaan aplikasi PJJ dan pengembangan bahan ajar yang diikuti oleh dosen, guru, dan mahasiswa yang dilaksanakan secara online melalui kegiatan webinar. Kegiatan tersebut diikuti oleh 74 orang peserta yang terdiri dari dosen, guru, dan mahasiswa. Implikasi dari kegiatan tersebut adalah peserta mendapat pengetahuan penggunaan aplikasi PJJ dan dapat menerapkan dalam proses pembelajaran daring.
\end{abstract}

Kata Kunci: Aplikasi pembelajaran jarak jauh; pengembangan bahan ajar; covid-19

\begin{abstract}
Distance learning has been known and applied for a long time through programs organized by the Open University and by several other universities. The implementation is by learning through modules and students take exams at the end of the semester directly or offline. However, since the end of 2019 with the Covid-19 outbreak, the implementation of distance learning has become a must for schools and universities. The implementation of distance learning in the Covid-19 era is very different from the distance learning implemented by the Open University at that time. Distance learning is currently carried out through the internet network or commonly referred to as online learning. To support this implementation, lecturers, students, teachers, and students are required to master the use of applications that can be used in the online learning process, such as zoom, google meet, whatsshap, and several other applications. For this reason, the STKIP Bima mathematics education study program held a socialization of the use of the PJJ application and the development of teaching materials which were attended by lecturers, teachers, and students which were carried out online through webinars. The activity was attended by 74 participants consisting of lecturers, teachers, and students. The implication of this activity is that participant's gain knowledge of using the PJJ application and can apply it in the online learning process.
\end{abstract}

@ 2021 JagoMipa (https://bimaberilmu.com/jurnal/index.php/jagomipa) 
Keywords: distance learning; application; teaching materials; covid-19

\section{PENDAHULUAN}

Wabah Covid-19 memberikan dampak kepada seluruh aktivitas manusia dibatasi, termasuk kegiatan pembelajaran, baik di jenjang sekolah dasar sampai jenjang perguruan tinggi mulai menerapkan kegiatan pembelajaran jarak jauh (PJJ). Hal ini dilakukan untuk membatasi dan menghindari penyebaran virus yang masif. Kebijakan belajar dari rumah mulai diterapkan pada tanggal 9 Maret 2020 setelah menteri pendidikan dan kebudayaan mengeluarkan surat edaran nomor 2 tahun 2020 dan nomor 3 tahun 2020 tentang pembelajaran secara daring dan bekerja dari rumah dalam rangka pencegahan penyebaran Corona Virus Disease (COVID-19).

Seluruh pimpinan perguruan tinggi di setiap daerah yang terdampak, diminta untuk menghentikan aktivitas kegiatan akademik seperti perkuliahan secara tatap muka. Sebagai tindak lanjut dari surat edaran tersebut seluruh perguruan tinggi juga diminta untuk mengeluarkan kebijakan tentang proses pembelajaran secara daring bagi mahasiswa. Oleh karenanya semua perguruan tinggi di Indonesia melakukan penyesuaian terhadap kebijakan ini dalam merubah seluruh kegiatan belajar mengajar dilakukan secara daring.

Selain itu, kesulitan yang dialami oleh dosen, mahasiswa, maupun guru dalam menggunakan aplikasi pembelajaran daring menjadi faktor penting dilaksanakan kegiatan soseiliasi ini. Mahasiswa pendidikan matematika sangat kesulitan memahami matakuliah yang sifatnya hitungan dalam pembelajaran dadring (Syarifuddin et al., 2021). Pembelajaran daring tidak efektif dilaksanakan jika sarana pendukung tidak memadai (Ameli et al., 2020), dan keseiapan guru maupun dosen dalam mempersiapkan pembelajaran (Fauziyah, 2020; Sadikin \& Hamidah, 2020).

Sesuai edaran ketua STKIP Bima nomor 0271/AK-II.03/2020 tertanggal 21 September 2020 tentang perkuliahan semester Ganjil Tahun Akademik 2020/2021 yang harus dilakukan secara daring, maka dipandang perlu untuk membakali dosen tentang pengenalan dan penggunaan aplikasi yang digunakan saat pembelajaran jarak jauh. Disamping itu, dosen juga perlu dibekali dengan cara mengembangkan bahan ajar yang dapat digunakan saat pembelajaran jarak jauh.

Menindaklanjuti kebijakan pemerintah pusat, pemerintah daerah, dan edaran ketua STKIP Bima, maka program studi Pendidikan Matematika menginisiasi sebuah kegiatan webinar penggunaan aplikasi PJJ dan pengemabangan bahan ajar. Sebagai bentuk pengabdian, kegiatan tersbut dibuka secara umum, agar dosen dan mahasiswa dari berbagai kampus dapat berpartisipasi dalam kegiatan tersebut. Serta kegiatan tersebut dapat juga diikuti oleh para guru yang menerapkan pembelajaran jarak jauh.

\section{METODE PELAKSANAAN KEGIATAN}

Kegiatan webinar ini bertujuan untuk meningkatkan pengetahuan, pemahaman, dan penggunaan aplikasi pembelajaran jarak jauh dan pengembangan bahan ajar bagi dosen, mahasiswa, dan guru. Adapun tema kegiatan adalah "Peningkatan Kapasitas Pengajar dalam Mengembangkan Bahan Ajar dan Pemanfaatan Aplikasi PJJ Menuju Pembelajaran yang Efefktif'.

Kegiatan ini diawali dengan perencanaan melalui kepanitian dan sosialisasi dalam bentuk flayer yang disebarkan melalui media sosial facebook dan whattshap.

@ 2021 JagoMipa (https://bimaberilmu.com/jurnal/index.php/jagomipa) 
Bentuk flayer tersebut seperti pada Gambar 1. Dalam flayer tersebut dimuat juga link pendaftaran yang dapat digunakan oleh peserta untuk pendaftaran secara online. Pendaftaran peserta dilakukan melalui google form yang telah disediakan oleh kepanitiaan yaitu pada link: https://s.id/WebinarProdiMat1.

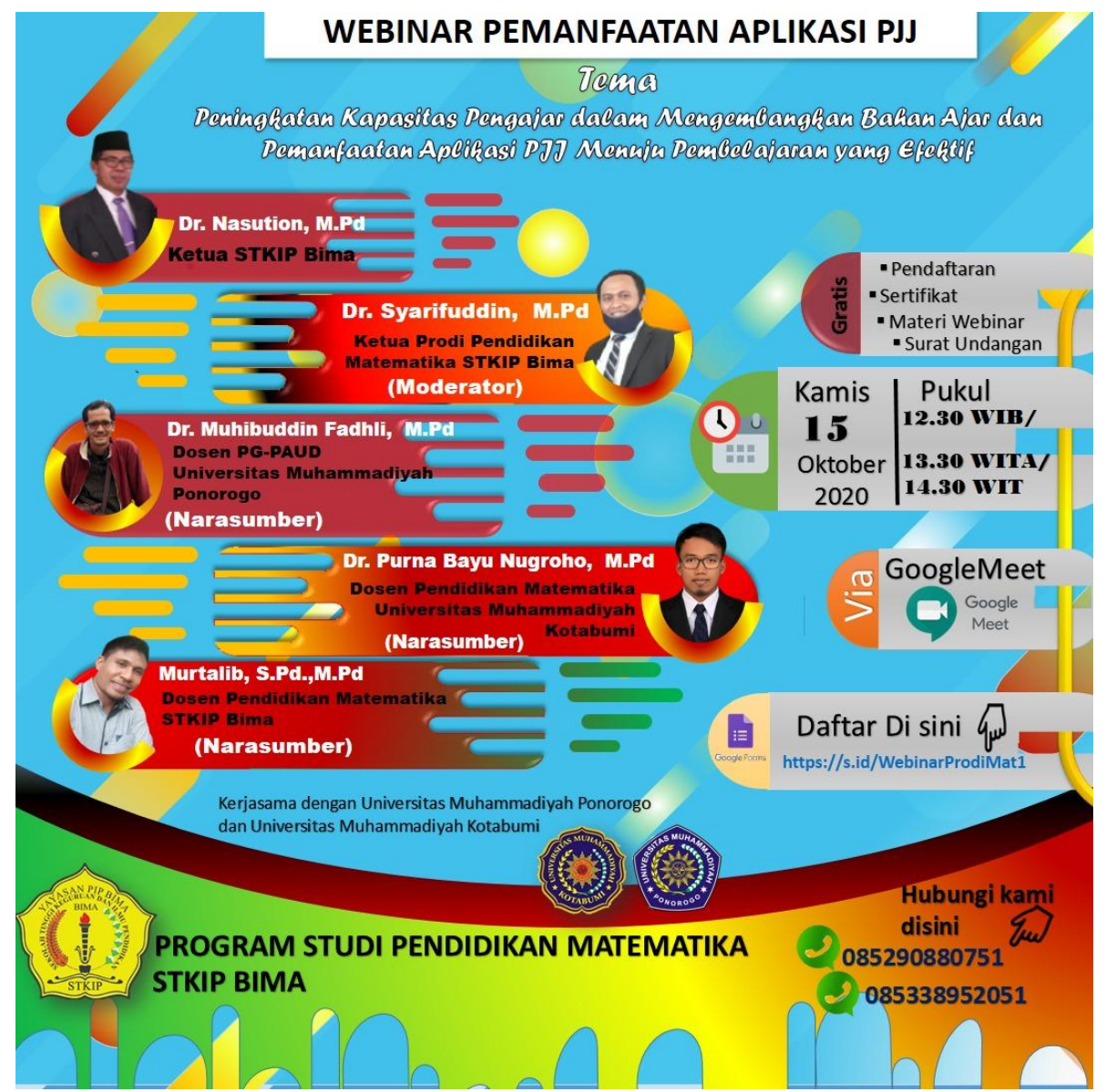

Gambar 1. Flayer sosialisasi webinar aplikasi pembelajaran jarak jauh

\section{Waktu dan Tempat Pelaksanaan}

Waktu pelaksanaan kegiatan adalah pada hari Kamis, tanggal 15 Oktober 2020, mulai pukul 13.30 Wita. Kegiatan dilaksanakan secara daring melalui aplikasi Zoom (https://us02web.zoom.us/j/2196045441?pwd=UDcxVnNqM0VId2JRMVArSnpTM 1gxQT09).

\section{Panitia Pelaksana Kegiatan}

Tabel 1. Susunan kepanitiaan webinar aplikasi PJJ dan pengembangan bahan ajar

\begin{tabular}{|l|l|l|}
\hline No. & \multicolumn{1}{|c|}{$\begin{array}{c}\text { Jabatan dalam } \\
\text { kepanitiaan }\end{array}$} & \multicolumn{1}{c|}{ Nama } \\
\hline 1. & Pengarah & $\begin{array}{l}\text { Dr. Nasution, M.Pd. (Ketua STKIP } \\
\text { Bima) }\end{array}$ \\
\cline { 3 - 3 } & $\begin{array}{l}\text { Muhammad Satriawan, S.Pd., M.Pd. } \\
\text { (Wakil Ketua Bidang Akademik }\end{array}$ \\
\hline 2. & $\begin{array}{l}\text { Penaggung Jawab (Ketua } \\
\text { Panitia) }\end{array}$ & $\begin{array}{l}\text { Dr. Syarifuddin, S.Pd., M.Pd. } \\
\text { (Ketua Program Studi Pendidikan } \\
\text { Matematika) }\end{array}$ \\
\hline
\end{tabular}




\begin{tabular}{|l|l|l|}
\hline 3. & Bagian acara & $\begin{array}{l}\text { Mutmainah, S.Pd., M.Pd. } \\
\text { Muchlis, S.Pd., M.Pd.I. }\end{array}$ \\
\hline 4. & Bagian IT & $\begin{array}{l}\text { Murtalib, S.Pd., M.Pd. } \\
\text { Ika Wirahmad, S.Kom., M.Pd. } \\
\text { Dewi Sartika, S.Pd., M.Pd. }\end{array}$ \\
\hline 5. & $\begin{array}{l}\text { Bagian administrasi dan } \\
\text { dokumentasi }\end{array}$ & $\begin{array}{l}\text { Andang, M.Pd. } \\
\text { Edi Mulyadin, S.Pd., M.Pd. } \\
\end{array}$ \\
& & $\begin{array}{l}\text { Arnasari Merdekawati H, S.Pd., } \\
\text { M.Pd. }\end{array}$ \\
\hline
\end{tabular}

\section{Angaran Kegiatan}

Anggaran kegiatan berasal dari lembaga STKIP Bima yang merupakan dana penunjang kegiatan pengabdian internal yang menjadi anggaran rutin dalam pengembangan dan implementasi program kerja.

\section{IMPLEMENTASI KEGIATAN DAN PEMBAHASAN}

\section{Pendaftaran}

Pendaftaran peserta dilakukan melalui google form yang telah disediakan oleh kepanitiaan yaitu pada link: https://s.id/WebinarProdiMat1 atau https://docs.google.com/forms/d/e/1FAIpQLSei7yyIXoYgevQ8dsQxNARvg4uQNf AKE7w32GFM0tPyj3mPjg/viewform. Jumlah peserta yang melakukan registrasi adalah sebanyak 158 orang, yang terdiri dari dosen dan mahasiswa STKIP Bima, dosen dan mahasiswa dari beberapa perguruan tinggi luar STKIP Bima, dan guru.

\section{Narasumber}

Tabel 2. Narasumber kegiatan webinar aplikasi pembelajaran jarak jauh

\begin{tabular}{|l|l|l|}
\hline No & \multicolumn{1}{|c|}{ Nama } & \multicolumn{1}{|c|}{ Asal Institusi } \\
\hline 1. & Dr. Purna Bayu Nugroho, M.Pd. & $\begin{array}{l}\text { Universitas Muhammadiyah } \\
\text { Kotabumi }\end{array}$ \\
\hline 2. & Dr. Muhibuddin Fadhil, M.Pd. & $\begin{array}{l}\text { Universitas Muhammadiyah } \\
\text { Ponorogo }\end{array}$ \\
\hline 3. & Murtalib, S.Pd., M.Pd. & STKIP Bima \\
\hline
\end{tabular}

\section{Partisipasi Peserta}

Peserta yang berpartisipasi sebanyak 74 orang. Adapun kegiatan ini dilakukan siaran langsung melalui chanal youtube pada link https://www.youtube.com/channel/UC6t-UsB83vynw0HZ4xiy-wQ. 


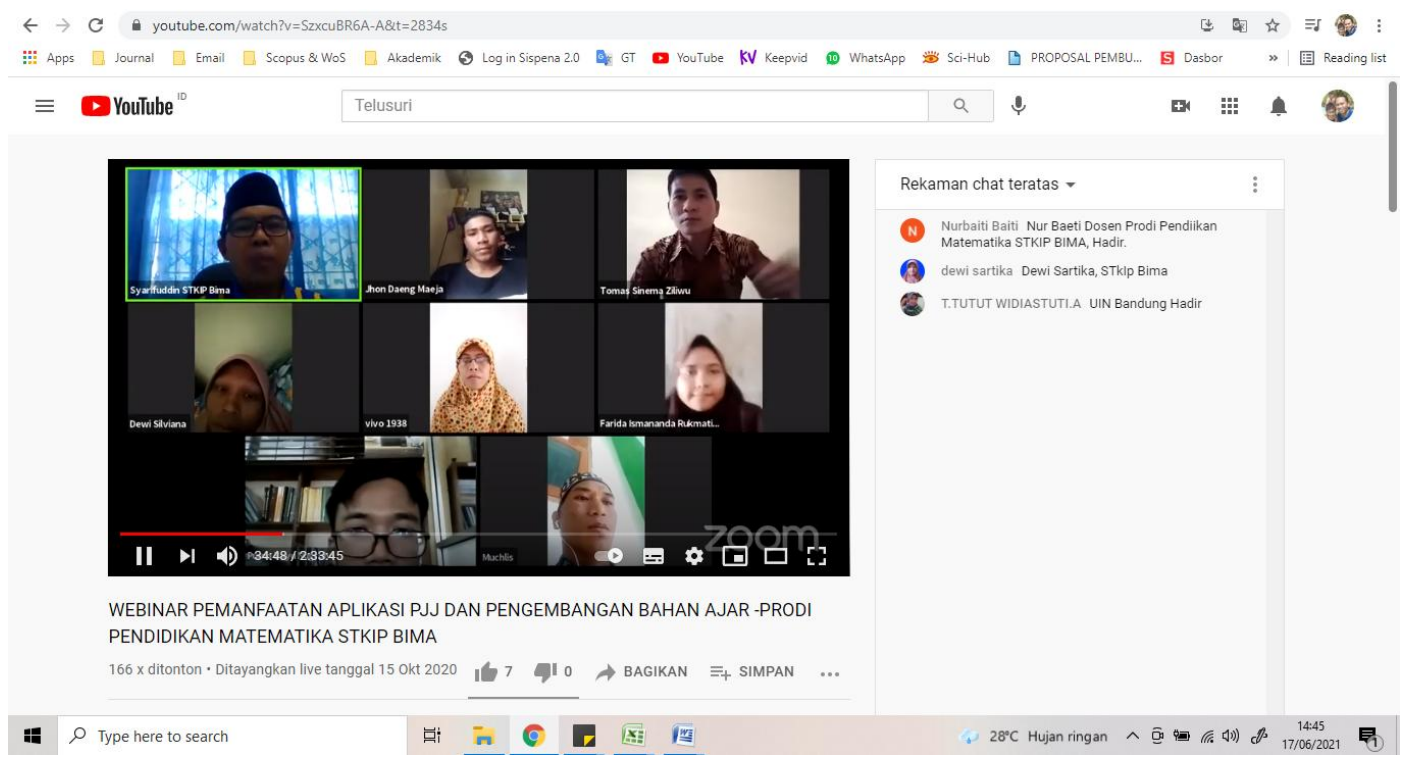

Gambar 2. Tampilan kegiatan webinar sosialiasi aplikasi pembelajaran jarak jauh dan pengembangan bahan ajar.

\section{Seritifikat Kegiatan}

Sertifikat diberikan kepada narasumber dan peserta yang mengikuti webinar sampai akhor kegiatan yang dibuktikan dengan daftar hadir. Sertifikat didistribusikan melalui email peserta yang digunakan pada saat mengisi daftar hadir. Sertifikat dan materi webinar dapat diunduh melalui google drive yang telah disediakan oleh kepanitiaan melalui link s.id/dokumenwebinar_prodimatstkipbima1 atau melalui https://drive.google.com/drive/folders/1Qhn439XOSC6xtntaIyTCQiTtnVPRjYto.

Adapun materi dari ketiga narasumber tersebut seperti pada tampilan Gambar 3, Gambar 4, dan Gambar 5.

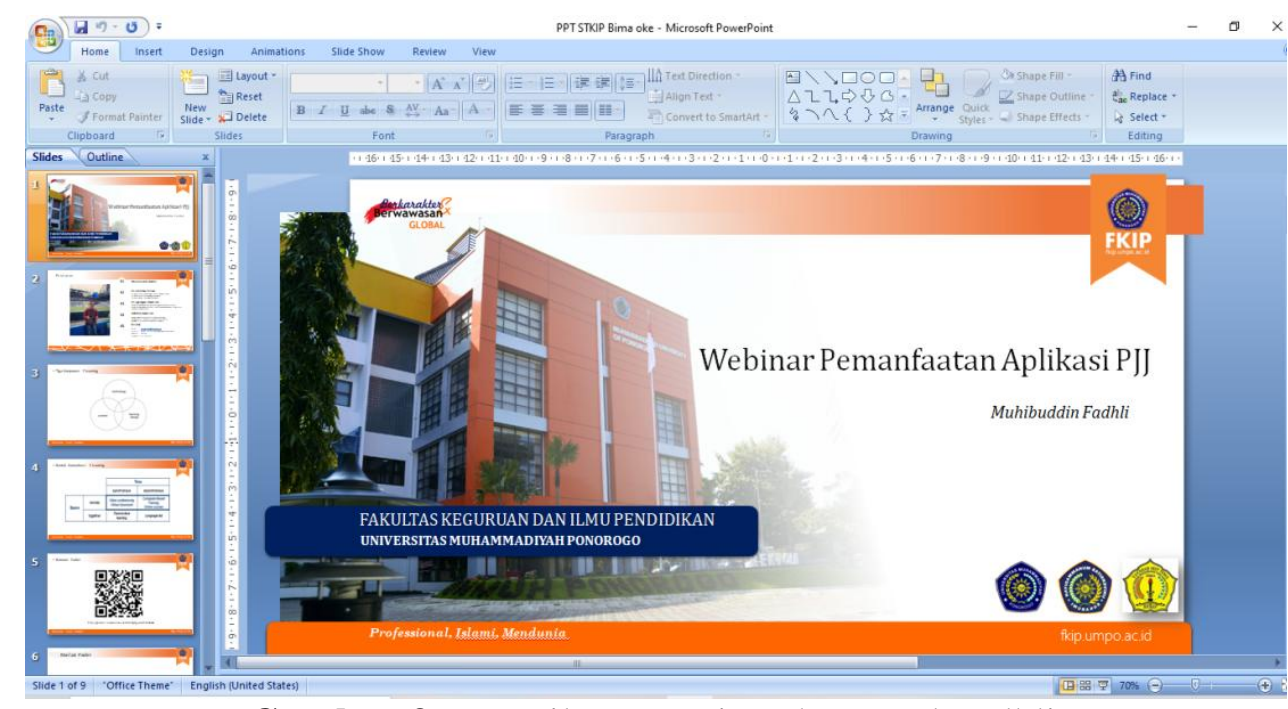

Gambar 3. Tampilan materi Muhammad Fadhli 


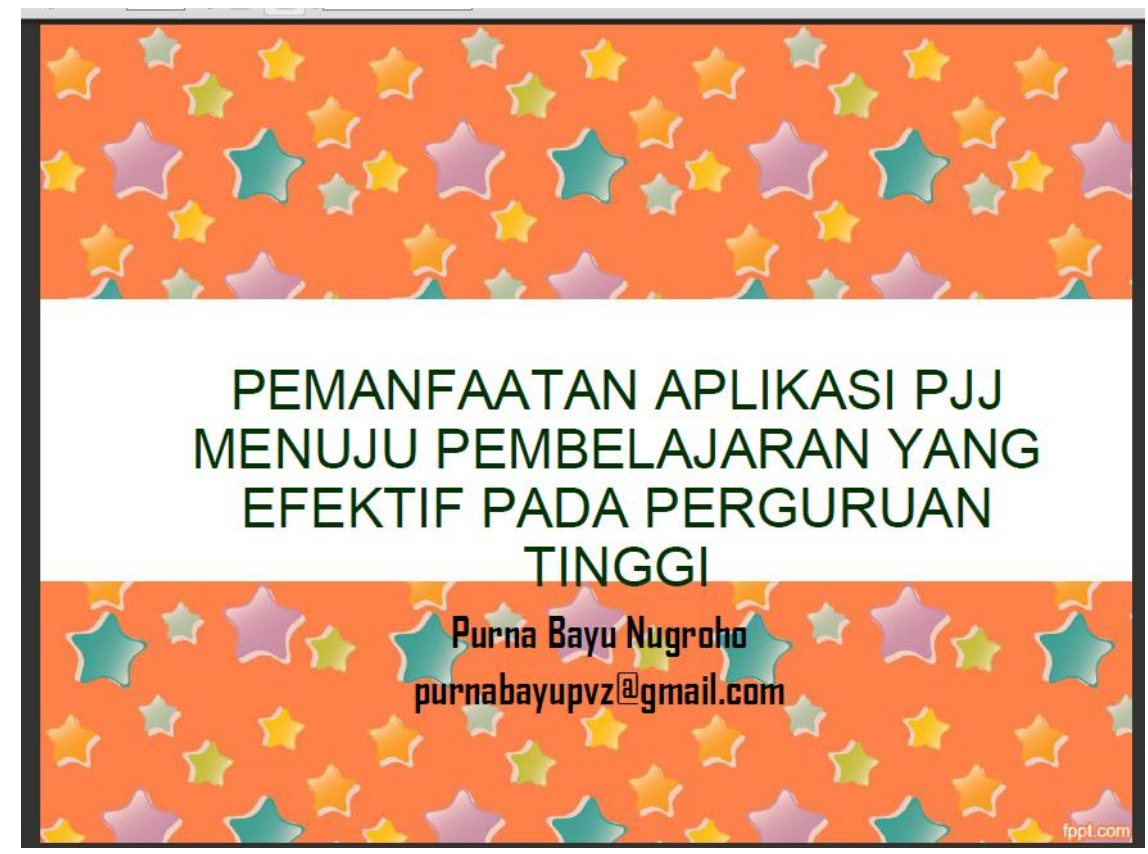

Gambar 4. Tampilan materi Purna Bayu Nugroho

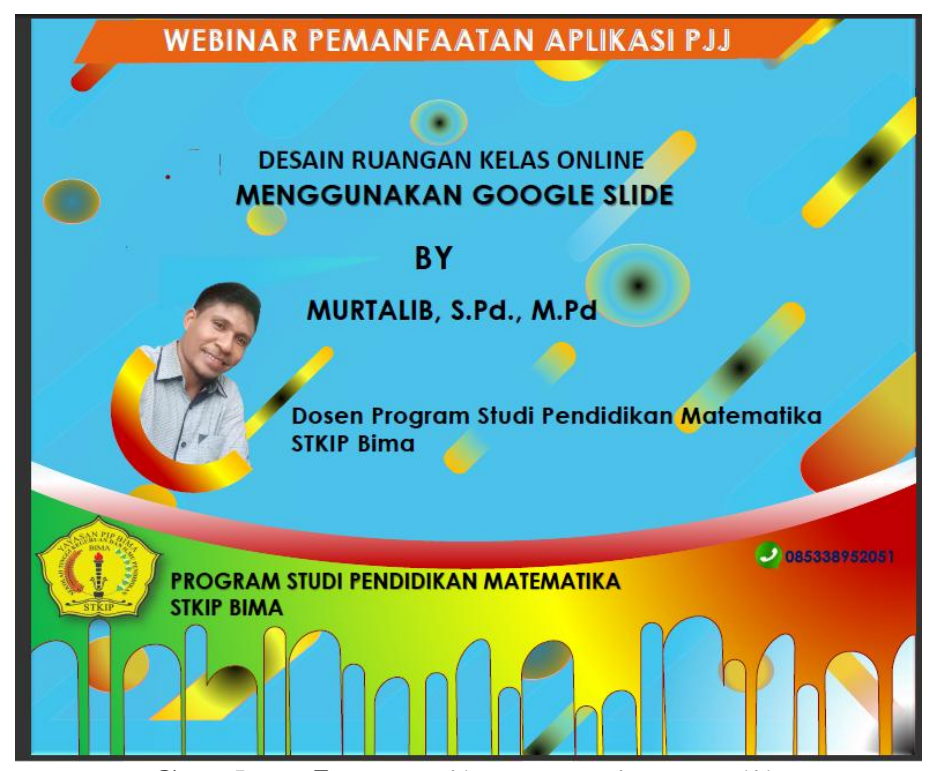

Gambar 5. Tampilan materi Murtalib

\section{KESIMPULAN}

Kegiatan webinar pemanfaatan aplikasi pembelajaran jarak jauh (PJJ) dan pengembangan bahan ajar memberikan pengalaman dan informasi tambahan kepada para peserta tentang penerapan beberapa aplikasi yang dapat digunakan untuk pembelajaran ditengah pandemi Covid-19. Dosen, guru, dan mahasiswa memiliki ilmu tambahan dalam mendesain bahan ajar yang digunakan dalam pembelajaran jarak jauh. Tindak lanjut dari kegiatan ini adalah memberikan bimbingan dan pendampingan kepada dosen, guru, dan mahasiswa, terutama yang berada dilingkup program studi pendidikan matemtika STKIP Bima dalam pemnafaatan aplikasi PJJ dan pengembangan bahan ajar. 


\section{DAFTAR PUSTAKA}

Ameli, A., Hasanah, U., Rahman, H., \& Putra, A. M. (2020). Analisis keefektifan pembelajaran online di masa pandemi COVID-9. Mahaguru: Jurnal Pendidikan Guru Sekolah Dasar, 2(1), 28-37.

Fauziyah, N. (2020). Dampak Covid-19 Terhadap Efektivitas Pembelajaran Daring Pendidikan Islam. Al-Mau'izhoh, 2(2).

Sadikin, A., \& Hamidah, A. (2020). Pembelajaran Daring di Tengah Wabah Covid19: (Online Learning in the Middle of the Covid-19 Pandemic). Biodik, 6(2), 214-224.

Syarifuddin, S., Basri, H., Ilham, M., \& Fauziah, A. F., 2021). Efektifitas Pembelajaran Daring Mahasiswa Pendidikan Matematika ditengah Pandemi Covid-19. JagoMIPA: Jurnal Pendidikan Matematika dan IPA, 1(1). 1-8. 